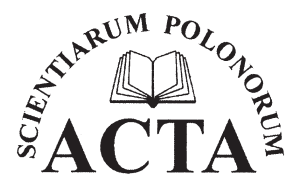

acta_architectura.sggw.pl

\title{
URSYNOWSKA SZKOŁA ARCHITEKTURY KRAJOBRAZU - MISTRZOWIE I ICH DZIEŁO (cZ. 1)
}

\author{
Jan Łukaszkiewicz ${ }^{\bowtie}$, Beata Fortuna-Antoszkiewicz, Edyta Rosłon-Szeryńska
}

Wydział Ogrodnictwa, Biotechnologii i Architektury,

Szkoła Główna Gospodarstwa Wiejskiego w Warszawie, Warszawa

\begin{abstract}
STRESZCZENIE
Jakość życia, szczególnie w miastach, zależy od odpowiednio ukształtowanej i zorganizowanej przestrzeni, dostosowanej do określonych funkcji i potrzeb jej użytkowników - niezależnie od czasów i trendów designu. Dawne parkoznawstwo, dzisiejsza architektura krajobrazu, wyrosły na gruncie wielowiekowej tradycji planowania ogrodów i parków. W Polsce prekursorem nauczania na poziomie wyższym i kształcenia adeptów tego zawodu była Szkoła Główna Gospodarstwa Wiejskiego z siedzibą w Warszawie, a ostatecznie na warszawskim Ursynowie - w dawnym majątku Juliana Ursyna Niemcewicza, wcześniejszej XVIII-wiecznej Rozkoszy. Tak narodziła się tzw. ursynowska szkoła architektury krajobrazu. Profil szkoły kształtowało kilka generacji wybitnych twórców, którzy przyczynili się do rozwoju architektury krajobrazu na SGGW i w Polsce. Te niekwestionowane osobowości pozostawiły po sobie wiele doskonałych realizacji reprezentujących najwyższe standardy. Obiekty te funkcjonują do dzisiaj, skutecznie wzbogacając krajobraz oraz miejskie systemy przyrodnicze. Liczne opracowania teoretyczne ich autorstwa stanowią fundament dla dalszych dociekań w obrębie dyscypliny architektury krajobrazu. Artykuł jako pierwsza część opracowania o polskich architektach krajobrazu prezentuje sylwetki: Franciszka Krzywda-Polkowskiego - założyciela kierunku na SGGW, twórcy parku w Żelazowej Woli); Alfonsa Zielonki - skutecznego orędownika zlokalizowania siedziby SGGW na Ursynowie; Zygmunta Hellwiga - projektanta parków Warszawy i wybitnego znawcy roślin; Aliny Scholtz - cenionej na świecie współzałożycielki International Federation of Landscape Architecture (IFLA). Niniejsza publikacja ma na celu przybliżenie sylwetek nestorów polskiej architektury krajobrazu, aby poprzez pryzmat ich działalności ukazać specyfikę i charakter tzw. szkoły ursynowskiej. Podstawą studiów i analiz był szeroki przegląd literatury, dokonań projektowych oraz badania terenowe w wybranych obiektach.
\end{abstract}

Słowa kluczowe: architektura krajobrazu, Ursynów, Franciszek Krzywda-Polkowski, Alfons Zielonko, Zygmunt Hellwig, Alina Scholtz

\section{WSTĘP}

Dzieło mówi wiele o swoim twórcy - o jego warsztacie naukowym i artystycznym, osobowości, wrażliwości na otaczający świat. Dzieła architektury krajobrazu - parki, ogrody, całe fragmenty krajobrazu - mimo że w przeciwieństwie np. do obiektów architektonicznych podlegają dynamicznym procesom zmian, a nawet znacznym przekształceniom (rozwój roślin- ności, zmiany sposobu zagospodarowania), stanowią wraz z upływającym czasem trwałą wartość społeczną i odzwierciedlenie trendów oraz sposobów myślenia w kolejnych dziesięcioleciach o ładzie przestrzennym, funkcjonowaniu i organizowaniu przestrzeni, życiu minionych pokoleń. Nie jest przypadkiem, że początek XX wieku wraz z rozwojem nowoczesnych teorii w urbanistyce (Howard, 1902; Le Corbusier, 1923 [2012]; Tołwiński, 1937, 1939, 1963; Lynch,

$凶_{\text {jan_lukaszkiewicz@sggw.pl }}$ 
1960; Schultz, 1971) stał się w wielu krajach na całym świecie - szczególnie w USA, Europie i Ameryce Południowej - czasem narodzin nowej dyscypliny związanej z kształtowaniem przestrzeni - architektury krajobrazu, której prekursorem (w tym autorem nazwy - ang. landscape architecture) był Frederick Law Olmsted, wybitny projektant amerykańskich parków w drugiej połowy XIX wieku (Rybczyński, 2000).

W Polsce narodziny architektury krajobrazu w dwudziestoleciu międzywojennym w specyficzny sposób wiązały się także $\mathrm{z}$ odrodzeniem Państwa Polskiego po długim okresie 123 lat zaborów i wielką potrzebą zatrudnienia specjalistów zajmujących się zawodowo i profesjonalnie rodzimym krajobrazem - zurbanizowanym i otwartym - często zaniedbanym, a wręcz zdewastowanym rabunkową gospodarką zaborców. Sama architektura krajobrazu, określana pierwotnie jako parkoznawstwo, wyrosła na gruncie kultywowanej w Polsce wielowiekowej tradycji planowania ogrodów i parków - miejsc przeznaczonych do wypoczynku i kontemplowania piękna „zapisanego” w naturze. W dwudziestoleciu międzywojennym prekursorem nauczania na poziomie wyższym i kształcenia adeptów tego zawodu stała się Szkoła Główna Gospodarstwa Wiejskiego z siedziba w Warszawie, a ostatecznie na warszawskim Ursynowie - w dawnym majątku Juliana Ursyna Niemcewicza, wcześniejszej XVIII-wiecznej

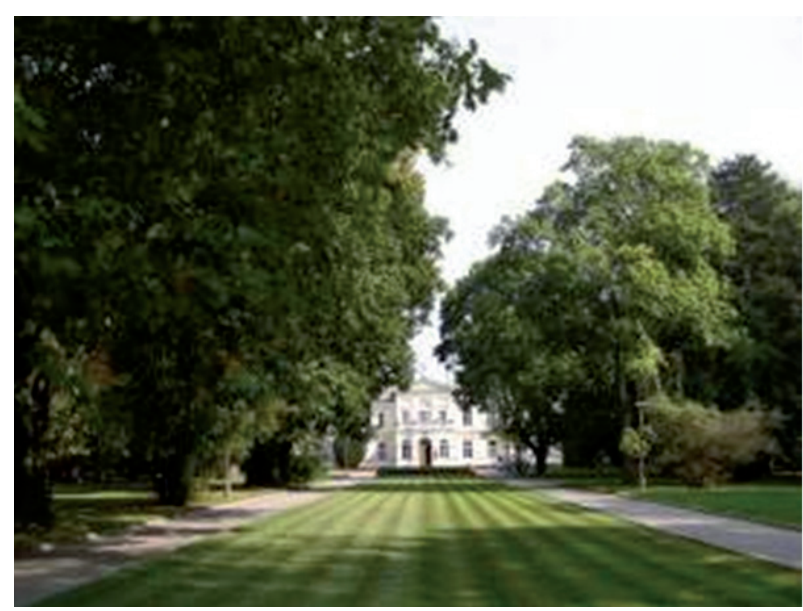

Rys. 1. Siedziba SGGW w Ursynowie, 2015 rok (fot. B. Fortuna-Antoszkiewicz)

Fig. 1. The headquarters of WULS-SGGW in Ursynów, 2015 (photo by B. Fortuna-Antoszkiewicz)
Rozkoszy (rys. 1-2). Tak narodziła się w Warszawie tzw. ursynowska szkoła architektury krajobrazu.

Początki kierunku architektura krajobrazu w SGGW sięgają końca lat 20. XX wieku. W roku akademickim 1929/1930 na Wydziale Ogrodniczym SGGW powołano specjalizację w zakresie projektowania oraz urządzania parków i ogrodów, której zaczątkiem były prowadzone już wcześniej (w roku akademickim 1928/1929) wykłady i ćwiczenia $\mathrm{z}$ dziedziny parkoznawstwa. W kolejnym roku akademickim (1930/1931) Rada Wydziału Ogrodniczego SGGW zadecydowała o powstaniu Zakładu Architektury Krajobrazu i Parkoznawstwa (z siedzibą w Skierniewicach, od 1936 r. przy ul. Rakowieckiej w Warszawie) - pierwszej jednostki organizacyjnej tego rodzaju w Polsce.

Poprzez lata 30. XX wieku, a następnie okres drugiej wojny światowej i czas powojenny profil ursynowskiej szkoły architektury krajobrazu kształtowało kilka generacji wybitnych twórców - architektów krajobrazu przekazujących swoje doświadczenia następcom w relacji mistrz - uczeń, którzy przyczynili się do rozwoju architektury krajobrazu na SGGW i w Polsce. Te niekwestionowane osobowości pozostawily po sobie wiele doskonałych realizacji, w tym obiektów publicznych, reprezentujących najwyższe standardy. Obiekty te nadal funkcjonują, ciesząc się niesłabnącą popularnością i skutecznie wzbogacając

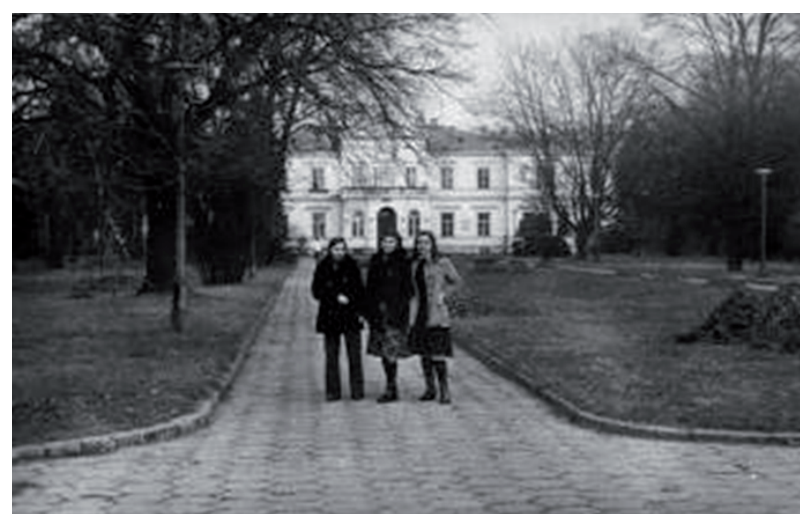

Rys. 2. Studentki Sekcji Kształtowania Terenów Zieleni w parku ursynowskim, 1976 r. (fot. ze zbiorów arch. kraj. E. Lewickiej)

Fig. 2. Students of the Section of Green Areas' Shaping in the Ursynów Park, 1976 (photo from landscape architect E. Lewicka's collection) 
krajobraz oraz miejskie systemy przyrodnicze. Liczne opracowania teoretyczne ich autorstwa stanowią fundament dla dalszych dociekań w obrębie dyscypliny architektury krajobrazu (np. Z. Hellwig, B. Lisiak, W. Sieroszewski, K. Wizner i A. Zielonko, Urzadzanie terenów zielonych, 1953; Z. Hellwig Byliny w parku i ogrodzie, 1957; Kwietniki, 1959; W. Niemirski (red.), Ksztaltowanie terenów zieleni, 1973; L. Majdecki, Historia ogrodów, 1981; Ochrona i konserwacja zabytkowych założeń ogrodowych, 1993). Już blisko 90-letnia tradycja i historia kierunku architektury krajobrazu w SGGW zachęca do spojrzenia na sylwetki tych twórców i przypomnienia pokrótce ich działalności zawodowej oraz licznych dzieł. W artykule zostały zaprezentowane biogramy: Franciszka Krzywda-Polkowskiego - założyciela kierunku na SGGW, twórcy parku w Żelazowej Woli; Alfonsa Zielonki - skutecznego orędownik zlokalizowania siedziby SGGW na Ursynowie; Zygmunta Hellwiga - projektanta parków Warszawy i wybitnego znawcy roślin; Aliny Scholtz - cenionej na świecie współzałożycielki International Federation of Landscape Architecture (IFLA).

\section{CEL I METODY}

Niniejsza publikacja ma na celu przybliżenie sylwetek nestorów polskiej architektury krajobrazu - aby poprzez pryzmat ich działalności ukazać specyfikę i charakter ursynowskiej szkoły architektury krajobrazu. Podstawą studiów i analiz był szeroki przegląd literatury oraz dokonań projektowych wybranych twórców, a także wieloletnie badania terenowe prowadzone w wybranych obiektach - na terenie Warszawy i Polski.

\section{WYNIKI}

\section{Franciszek Krzywda-Polkowski (1881-1949)}

Wychodząc naprzeciw realiom i potrzebom społecznym, w roku akademickim 1930/1931 Rada Wydziału
Ogrodniczego SGGW powierzyła zorganizowanie nowej jednostki - Zakładu Architektury Krajobrazu i Parkoznawstwa $1^{2}$ - prof. arch. Franciszkowi Krzywda-Polkowskiemu, który w tym czasie był już kierownikiem katedry na Wydziale Architektury Politechniki Warszawskiej. Jak pokazał czas, Franciszek KrzywdaPolkowski był osobą ze wszech miar predysponowaną do tego zadania. Posiadał wykształcenie architektoniczne (absolwent Moskiewskiego Państwowego Uniwersytetu Sztuki i Przemysłu im. S.G. Stroganowa, 1913 r.), poparte bogata praktyką zawodową (opracowania urbanistyczne nagradzane w konkursach, praca w biurach projektowych w kraju i za granica, funkcje w administracji publicznej, praca na uczelniach o profilu architektonicznym i sztuk pięknych). Wykazywał także duży talent organizacyjny (m.in. zorganizowanie we wrześniu 1918 r. Wydziału Architektoniczno-Budowlanego w Ministerstwie Robót Publicznych). Architekturą krajobrazu zainteresował się podczas swojego pobytu w Wielkiej Brytanii (w latach 1913-1914 odbywał roczny kurs urbanistyki w Londynie) i USA (w latach 1924-1925 studiował w Bostonie, Waszyngtonie, Nowym Jorku, gdzie pracował także w pracowni architektonicznej Mc Kim, Mead \& White) (Lenkiewicz, 1993).

Dorobek twórczy Franciszka Krzywda-Polkowskiego, przedstawiciela modernizmu, charakteryzuje wielka różnorodność i obejmuje m.in. projekty architektoniczne (np. gmachy urzędów i kościołów w Toruniu, Katowicach, Wilnie) i urbanistyczne, a także projekty parków, ogrodów i zieleni miejskiej, spośród których wiele nagrodzono (Lenkiewicz, 1993; Niemirski, 1995a). Jak podaje Rylke (2016), Franciszek KrzywdaPolkowski połączył pochodzący jeszcze z poprzedniej epoki angielski edwardiański styl malarski z nową zaczerpniętą z teorii Gestalt, opartą na zasadach percepcji dyspozycją form (brył i płaszczyzn). Podstawą kompozycji było w tym stylu wnętrze lub sekwencja wnętrz, które realizowano zgodnie z zasadami kompozycji ar-

\footnotetext{
${ }^{1}$ Podstawa prawna - Rozporządzenie Ministerstwa Wyznań Religijnych i Oświecenia Publicznego z dnia 26 września 1923 r. (§ 5), dotyczącym powołania specjalizacji w zakresie projektowania oraz urządzania parków i ogrodów na Wydziale Ogrodniczym SGGW (Piechna, 1995).

${ }^{2}$ Podstawa prawna - Rozporządzenie Ministerstwa Wyznań Religijnych i Oświecenia Publicznego z dnia 26 września 1923 r. (§ 5), dotyczącym powołania specjalizacji w zakresie projektowania oraz urządzania parków i ogrodów na Wydziale Ogrodniczym SGGW (Piechna, 1995)
} 
Łukaszkiewicz, J., Fortuna-Antoszkiewicz, B., Rosłon-Szeryńska, E. (2019). Ursynowska szkoła architektury krajobrazu - mistrzowie i ich dzieło (cz. 1). Acta Sci. Pol. Architectura 18 (1), 133-146, DOI: 10.22630/ASPA.2019.18.1.15

chitektonicznej, co jest wyraźnie widoczne w jego najważniejszym dziele - parku w Żelazowej Woli (realizacja 1932-1937; rys. 3-5) oraz w innych projektach parków, np.: w Jastrzębiej Górze (im. Derdowskiego), na skarpie w Płocku, na Górze Zamkowej w Nowogródku, parku uzdrowiskowego w Wiśle, parku Kościuszki w Katowicach (przebudowa), parku Zygmunta na Pradze (1923, I nagroda). Wśród innych jego

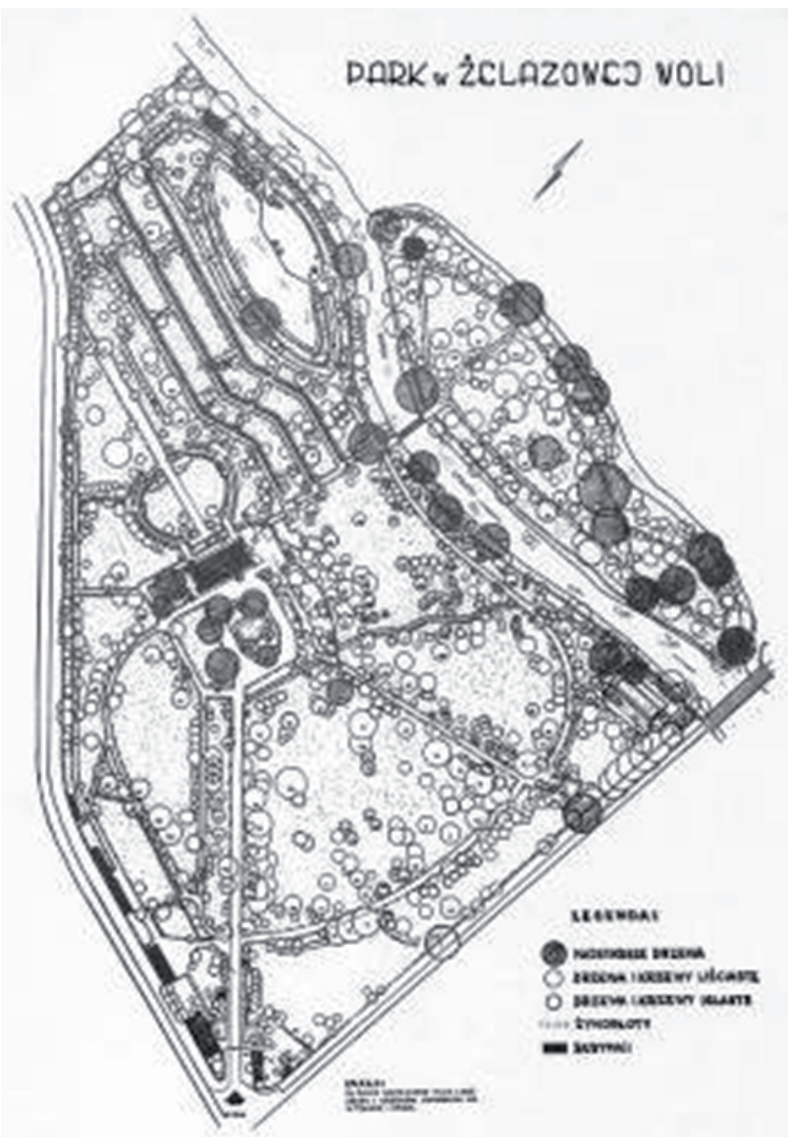

Rys. 3. Dzieło życia prof. Franciszka Krzywda-Polkowskiego - Park w Żelazowej Woli, zrealizowany w latach 1932-1937 (Majdecki, 1981)

Fig. 3. The work of life of prof. Franciszek Krzywda-Polkowski - Park in Żelazowa Wola, established in 1932-1937 (Majdecki, 1981) prac należy wymienić: plan Cmentarza Wojskowego na Powązkach w Warszawie, projekt układu terenów zieleni Wisły, projekt konkursowy Świątyni Opatrzności Bożej w Warszawie wraz z otaczającym parkiem²

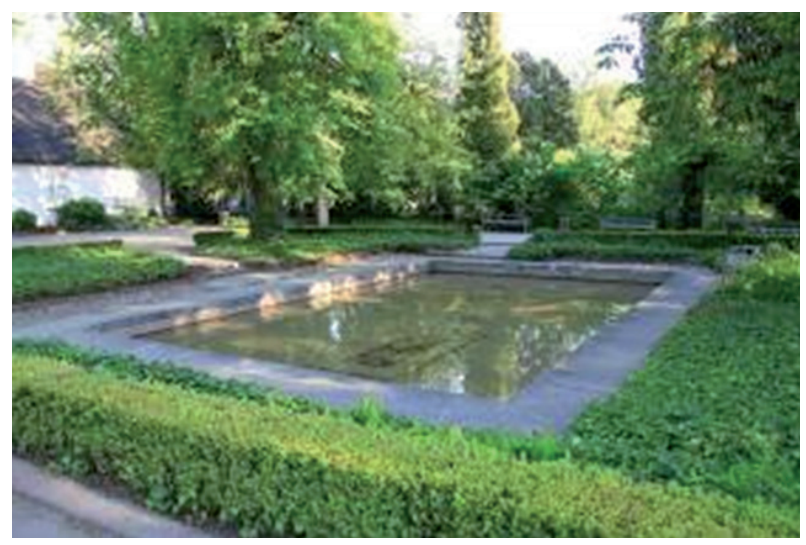

Rys. 4. Park w Żelazowej Woli - wnętrze frontowe przed dworkiem (fot. B. Fortuna-Antoszkiewicz, czerwiec 2016)

Fig. 4. Park in Żelazowa Wola - the front interior in front of the manor (photo by B. Fortuna-Antoszkiewicz, June 2016)
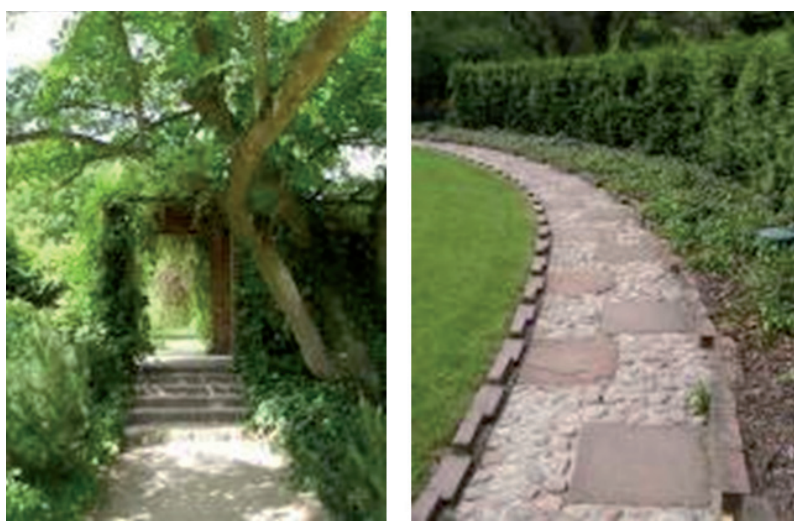

Rys. 5. Park w Żelazowej Woli - detale ogrodowe (fot. B. Fortuna-Antoszkiewicz, czerwiec 2016; maj 2012)

Fig. 5. Park in Żelazowa Wola - garden details (photo by B. Fortuna-Antoszkiewicz, June 2016, May 2012)

\footnotetext{
${ }^{2}$ W 1931 roku, na mocy ustawy z 17 marca 1921 roku, ogłoszono konkurs zamknięty na projekt Świątyni Opatrzności Bożej w Warszawie - dla dochowania ślubu Sejmu Czteroletniego. Wśród zaproszonych 18 uczestników konkursu (ostatecznie napłynęło 15 prac) jedynie opracowanie Krzywda-Polkowskiego obejmowało kompleksowo ujęty projekt budowli wraz z otoczeniem - park związany z architekturą i jej podporządkowany (Tkaczyk-Piechna, 1997).
} 
(Tkaczyk-Piechna, 1997). Opracował także regulacyjne plany rozbudowy: Sochaczewa, Torunia (1925), Kalisza (nagroda IV stopnia) oraz Powiśla w Warszawie (nagrodzone). Po drugiej wojnie światowej ponownie objął stanowiska profesora na Wydziale Politechniki Warszawskiej i na Wydziale Ogrodniczym SGGW. Od stycznia 1946 do maja 1947 roku z ramienia Kancelarii Cywilnej Prezydenta prof. Krzywda-Polkowski pracował przy urządzaniu parków reprezentacyjnych: Belweder, Łazienki Królewskie, Natolin. Z końcem 1947 roku był zaangażowany w Ministerstwie Odbudowy jako główny rzeczoznawca ds. projektowania zieleni. Zmarł nagle 29 listopada 1949 roku w swojej pracowni w SGGW (Lenkiewicz, 1993; MajdeckaStrzeżek, Niemirski i Szumański, b.d.).

Działalność profesora na niwie architektury krajobrazu miała charakter pionierski i zapoczątkowała rozwój tej dyscypliny w Polsce, kontynuowany później przez jego uczniów, m.in.: Alfonsa Zielonko, Alinę Scholtz, Władysława Niemirskiego, Ludwika Lawina (Niemirski, 1995a; Piechna, 1995).

\section{Alfons Zielonko (1907-1999)}

Po śmierci prof. Krzywda-Polkowskiego, pod koniec 1949 roku Rada Wydziału Ogrodniczego SGGW powierzyła kierownictwo jednostki (Zakładu Architektury Krajobrazu i Parkoznawstwa) adiunktowi Alfonsowi Zielonce. Jego osoba wiąże się nierozerwalnie z Ursynowem. Już w 1937 roku wygrał konkurs ogłoszony przez Ministerstwo Wyznań Religijnych i Oświecenia Publicznego na zaplanowanie terenu wzorcowej Szkoły Ogrodniczej przeniesionej do Ursynowa (rys. 6). Realizację zwycięskiego projektu przerwał wybuch drugiej wojny światowej. Posadzono jednak wiele drzew, które przetrwały wojnę i stanowią obecnie ozdobę parku (Niemirski, 1995b; Rylke i Dzięcioł, 1998; rys. 7).

Alfons Zielonko w 1936 roku ukończył Wydział Ogrodnictwa Ozdobnego w Państwowej Szkole Ogrodniczej w Poznaniu, a w 1946 roku Wydział Ogrodniczy SGGW i otrzymał dyplom inżyniera ogrodnika w zakresie architektury krajobrazu i parkoznawstwa. Promotorem pracy dyplomowej (Projekt rozplanowania terenu Państwowego Liceum Ogrodniczego w Ursynowie) był prof. Krzywda-Polkowski (Kiciński, 1995). Już w latach 1927-1931 Alfons Zielonko pra- cował w Biurze Projektów Dyrekcji Ogrodów Miejskich w Katowicach. Od 1933 roku był on instruktorem, a następnie nauczycielem w Szkole Ogrodniczej w Wilnie, skąd został przeniesiony do Szkoły Ogrodniczej w Warszawie. Nauczanie kontynuował w czasach okupacji - w Szkole Ogrodniczej II stopnia w Ursynowie, Miejskiej Szkole Ogrodniczo-Rolniczej II stopnia w Warszawie oraz na tajnych kompletach w SGGW. Po wojnie, do 1950 roku był nauczycielem i dyrektorem Liceum Ogrodniczego w Ursynowie. W 1949 roku został adiunktem na Wydziale Ogrodniczym SGGW i nauczał (pod kierunkiem prof. F. Krzywda-Polkowskiego) w zakresie architektury krajobrazu i parkoznawstwa (Niemirski, 1995b; Rylke i Dzięcioł, 1998). Równolegle w latach 1950-1953 pracował w Instytucie Urbanistyki i Architektury w Zakładzie Zieleni, gdzie tworzył m.in. normatywy urbanistyczne dla terenów zieleni. Zainicjował powstanie czasopisma Ogród, Park, Krajobraz (razem m.in. z Z. Helwigiem), przekształcone następnie w miesięcznik Ogrodnictwo, którego redaktorem naczelnym był przez 20 lat. W tym czasie opublikował ponad 100 artykułów popularyzujących architekturę krajobrazu. Jego ważniejsze prace projektowe to: Ogród Zoologiczny przy Parku Kościuszki w Katowicach, Park Ludowy w Poznaniu, zagospodarowanie placów Andrzeja i im. Księdza Londzina w Katowicach, Cmentarz Pomnik Obozu Zagłady Narodu Żydowskiego w Treblince i Ogrodu Botanicznego w Łodzi (wraz z W. Niemirskim), zagospodarowanie przestrzenne osiedla Szombierki, terenu Uniwersytetu w Lublinie (wraz z F. Krzywda-Polkowskim i W. Niemirskim), projekty ogrodów szkolnych (w Lidzie, Augustowie, Wilnie, Ursynowie), przedszkolnych (np. w Dąbrowie Górniczej), sportowych (w Serwach, Jeziorach, Wilnie). Uzyskał pierwsze nagrody w trzech poważnych konkursach za projekty: zagospodarowania przestrzennego Szkoły Ogrodniczej w Ursynowie, monumentu ku czci pomordowanych w Treblince oraz Ogrodu Botanicznego w Łodzi (rys. 8). Jego prace były prezentowane na wystawach ogrodniczych (Essen, Wiedeń, Zurich, Berlin, Praga, Sztokholm); na trzech (Warszawa, Łódź, Lwów) otrzymał srebrne medale za projekty terenów zieleni.

Uczestniczył w międzynarodowych kongresach IFLA, IFPRA (Wiedeń, Zurich, Londyn, Amsterdam, Bruksela, Stuttgart, Istambuł, Berlin Zachodni). 


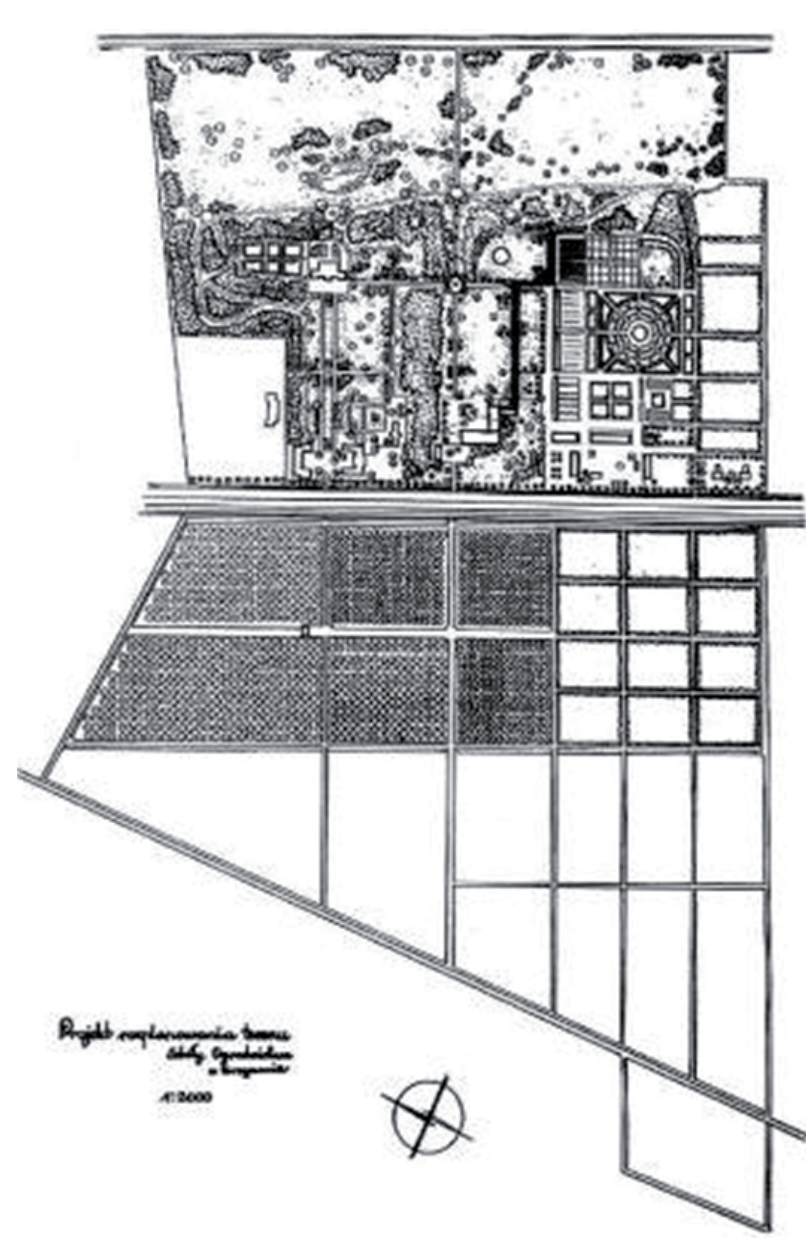

Rys. 6. Projekt rozplanowania terenów Państwowej Szkoły Ogrodnictwa w Ursynowie, proj. A. Zielonko, 1937 rok (Rylke i Dzięcioł, 1998)

Fig. 6. Project for the layout of the grounds of the State School of Horticulture in Ursynów, designed by A. Zielonko, 1937 (Rylke \& Dzięcioł, 1998)

Dorobek naukowy Alfonsa Zielonki obejmuje 41 prac badawczych, 103 popularnonaukowych, 51 referatów, doniesień i opracowań, współautorstwo 3 podręczników: pionierskie Dobory drzew, krzewów i bylin, 1951; Urzadzanie terenów zielonych, 1953; Ksztaltowanie terenów zieleni, 1973 (pod redakcją W. Niemirskiego, 1973) oraz skryptu Planowanie miast i osiedli. Zadania i cele planowania miejskich terenów zielonych, 1951. Piastował liczne funkcje w radach naukowych, komisjach, stowarzyszeniach. Był założycielem Stowarzyszenia Inżynierów i Techników Ogrodników (SITO), a następnie jego prezesem przez 18 lat. Był członkiem

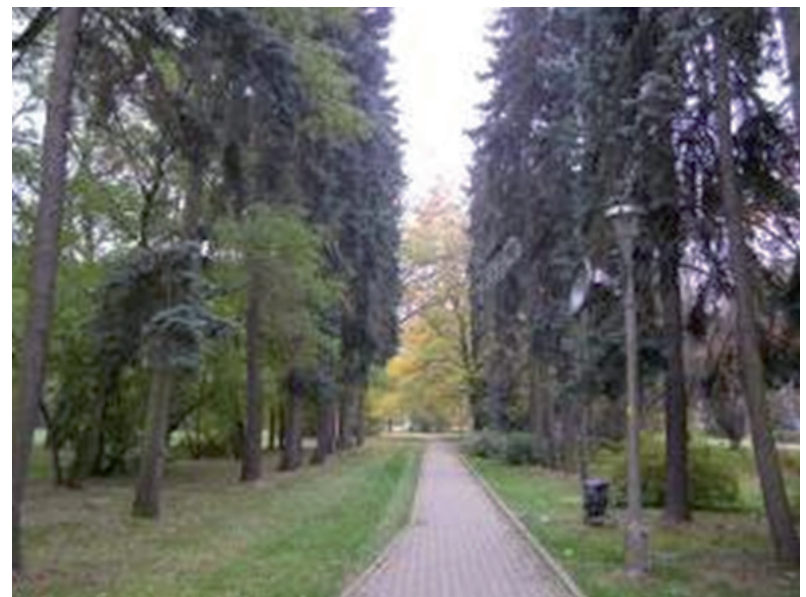

Rys. 7. Aleja świerkowa prowadząca do ursynowskiego pałacyku - zasadzona w 1939 roku według wskazówek A. Zielonki (fot. B. Fortuna-Antoszkiewicz, październik 2011)

Fig. 7. The spruce alley leading to the Ursynów Palace - planted in 1939 according to the instructions of A. Zielonko (photo by B. Fortuna-Antoszkiewicz, October 2011)

NOT, SARP, TUP, PTB, ISHS, IFLA, IFPRA. Otrzymał wiele ważnych nagród państwowych i odznaczeń, m.in.: Krzyż Komandorski i Krzyż Oficerski Orderu Odrodzenia Polski, Złoty Krzyż Zasługi, Złota Odznaka Honorowa NOT, Zasłużonego Działacza Kultury, złota odznaka „Za opiekę nad zabytkami” (Niemirski, 1995b; Rylke i Dzięcioł, 1998).

Profesor Alfons Zielonko był niezrównanym organizatorem, któremu szkoła architektury krajobrazu w Ursynowie zawdzięcza swój rozwój. W roku akademickim 1951/1952 przyczynił się do utworzenia Katedry Kształtowania i Zdobienia Krajobrazu. Następnie dzięki jego staraniom w 1954 roku Ministerstwo Szkolnictwa Wyższego wydało zgodę na powołanie pełnowymiarowych studiów dwustopniowych, dających kompletne przygotowanie do zawodu architekta krajobrazu. W tym samym roku Ministerstwo Szkolnictwa Wyższego powołało Sekcję Kształtowania Terenów Zieleni (SKTZ) w SGGW. Rok później (1955) w ramach Sekcji utworzono Katedrę Projektowania Terenów Zieleni (p.o. kierownika prof. W. Niemirski) oraz Katedrę Urządzania i Konserwacji Terenów Zieleni (kierownik prof. A. Zielonko) (Niemirski, 1995b; Rylke i Dzięcioł, 1998). 


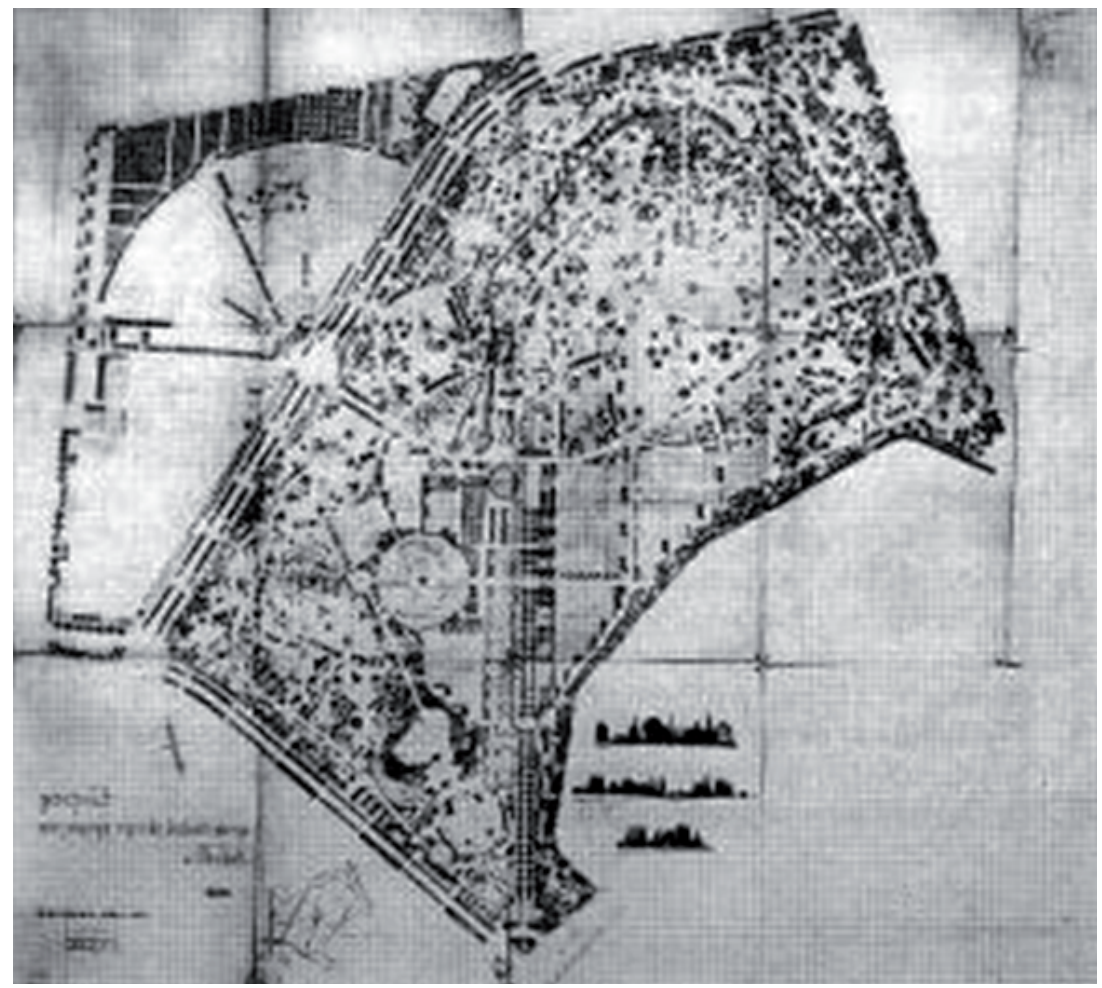

Rys. 8. Ogród Botaniczny w Łodzi, proj. W. Niemirski, A. Zielonko, 1947 rok - I miejsce w konkursie SARP (Rylke i Dzięcioł, 1998)

Fig. 8. The Botanical Garden in Łódź, designed by W. Niemirski, A. Zielonko, 1947 - 1st place in the SARP competition (Rylke \& Dzięcioł, 1998)

Profesorowi Zielonce Szkoła Główna Gospodarstwa Wiejskiego zawdzięcza swoją obecną siedzibę. W 1956 roku, z jego inicjatywy, ówczesnego prorektora SGGW, Ursynów wraz z pałacykiem Niemcewicza (dzisiejszy rektorat), parkiem oraz 81 ha okolicznych terenów przekazany został przez państwo Szkole, której siedziba dotychczas mieściła się w gmachach przy ul. Rakowieckiej ${ }^{3}$.

W grudniu 1956 roku do Ursynowa przeniesiono SKTZ. Od 1959 roku Sekcja miała oddzielny, pięcioletni plan i program nauczania, każdego roku przyjmowano od 15 do 30 słuchaczy. Dzieło, które zapoczątkował prof. Franciszek Krzywda-Polkowski, prof. Alfons Zielonko organizacyjnie rozwinął, przyczynia- jąc się do utworzenia jedynego, prężnie funkcjonującego akademickiego ośrodka architektury krajobrazu w Polsce tamtej doby. Był wybitnym człowiekiem i działaczem, uznanym twórcą polskiej szkoły architektury krajobrazu okresu powojennego, cenionym w kraju i za granicą (Rylke i Dzięcioł, 1998).

\section{Zygmunt Hellwig (1899-1958)}

Wybitny polski ogrodnik-architekt, twórca wielu ogrodów i parków, wielki znawca roślin. W wolnej Polsce w latach 1919-1922 studiował w Warszawie w Wyższej Szkole Ogrodniczej przy Wolnej Wszechnicy Polskiej. Praktyki zawodowe odbył w ogrodach botanicznych w Paryżu i londyńskim Kew (1923-

\footnotetext{
${ }^{3}$ Zajęcia z „kształtowania terenów zieleni” odbywały się w istniejącej do dziś willi przy ul. Madalińskiego 77, gdzie była m.in. kreślarnia i obszerny taras na pierwszym piętrze, wygodny do spotkań i rozmów (Dolatowski, 2016).
} 
-1924). W 1925 roku został kierownikiem działu w Zakładach Ogrodniczych we Fredrowie (pod kierunkiem Antoniego Wróblewskiego). Prowadził własne szkółki bylin, znane szeroko w Polsce i za granicą - Szkółkę Bylin i Roślin Skalnych Okóle pod egidą firmy swojego ojca Władysława oraz założony w 1926 roku wraz ze Zbigniewem Strausem - Zakład Bylin i Biuro Planowania Ogrodów w Bydgoszczy, a następnie w Błoniu koło Warszawy (Lenkiewicz, 1991; Kurzyńska, 2008). Biuro to zrealizowało około 130 ogrodów i parków na terenie całego kraju, m.in.: Park Zdrowia między tężniami, park przy termie i zieleńce w Ciechocinku (1931-1934). W 1935 roku Zygmunt Hellwig wyjechał do USA, gdzie kontynuował naukę zawodu w Szkole Architektury Krajobrazu Uniwersytetu Harvarda w Cambridge, Mass. Po powrocie w 1936 roku podjął pracę w Zarządzie Miejskim m.st. Warszawy na stanowisku kierownika Biura Projektów Wydziału Ogrodniczego. W tym samym roku współorganizował Stowarzyszenie Architektów Ogrodów Rzeczypospolitej Polskiej (SAO RP). Od 1924 roku zamieszczał artykuły w dwutygodniku Ogrodnik, a od 1925 roku w miesięczniku Przeglad Ogrodniczy (Tkaczyk-Piechna, 2000), w którym był współredaktorem w latach 1931-1939 (także po jego wznowieniu w 1949 r. aż do likwidacji w 1958 r.). Był autorem ponad 100 artykułów i notek z zakresu uprawy roślin ozdobnych oraz działalności SAO RP. W czasie okupacji pozostawał na tym stanowisku (do 1944 r.), organizując tymczasowe ogródki działkowe dla mieszkańców Warszawy. Prowadził tajny zespół projektowy, który pracował nad przyszłymi parkami ludowymi i sportowymi na Siekierkach i Kępie Potockiej (Lenkiewicz, 1991; Dolatowski, 2016). Po wojnie, w 1945 roku, na mocy ustawy z 21 września 1922 roku Zygmunt Hellwig otrzymał dyplom magistra inżyniera w Szkole Głównej Gospodarstwa Wiejskiego w Warszawie. Aktywnie działał przy odbudowie Stolicy, piastujacc stanowisko naczelnika Wydziału Planowania i Lokalizacji Terenów Zielonych Rady Narodowej w Warszawie. W 1947 roku został powołany na stanowisko adiunkta w Katedrze Sadownictwa Uniwersytetu im. Adama Mickiewicza w Poznaniu, aby zorganizować Zakład Planowania i Urządzania Terenów Zielonych.

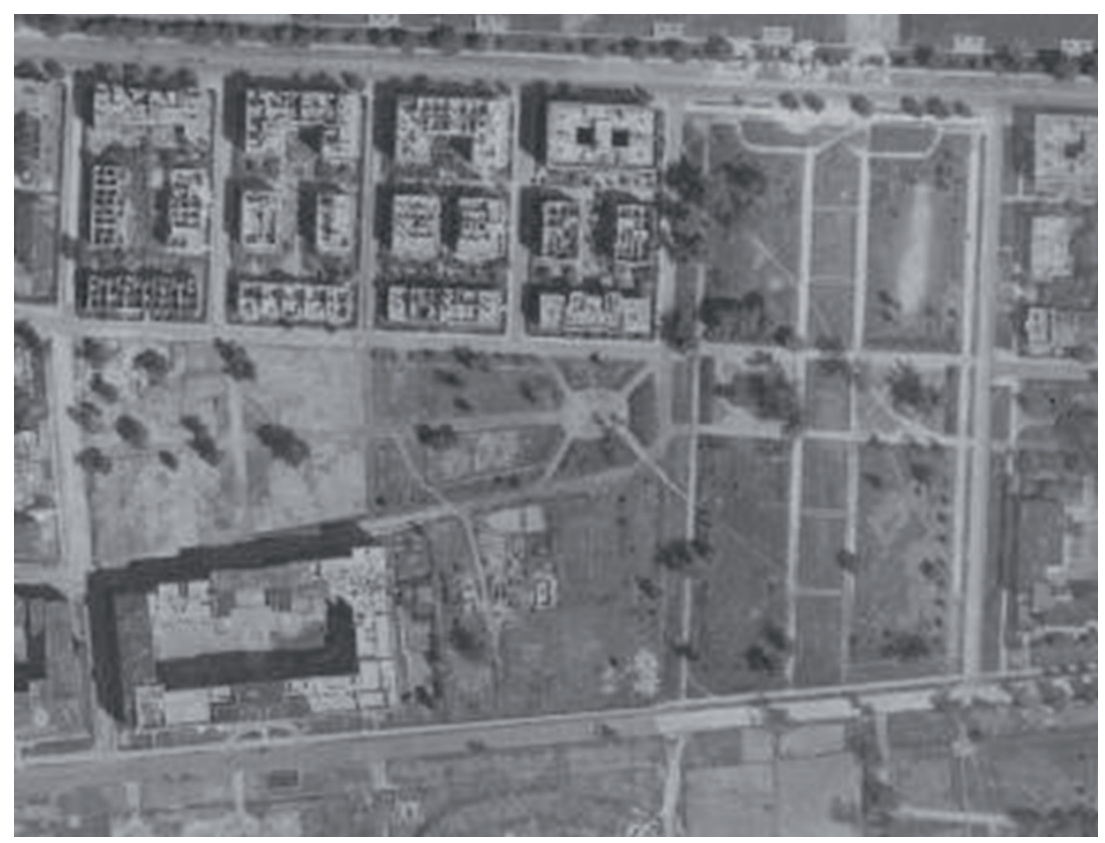

Rys. 9. Zieleniec Wielkopolski w Warszawie - stan w 1945 roku (http://www.mapa.um.warszawa.pl/mapaApp1/mapa? service=mapa_historyczna/1945 [dostęp: 07.10.2018])

Fig. 9. Zieleniec Wielkopolski in Warsaw - condition in 1945 (http://www.mapa.um.warszawa.pl/mapaApp1/mapa? service=mapa_historyczna/1945 [dostęp: 07.10.2018]) 
W 1948 roku na zaproszenie Zarządu Miejskiego we Wrocławiu Zygmunt Hellwig konsultował projektowanie zieleni w ramach Wystawy Ziem Odzyskanych, za co otrzymał dyplom uznania. W 1949 roku organizował pierwszą w kraju Pracownię Terenów Zielonych w Centralnym Biurze Projektów Architektonicznych i Budowlanych w Warszawie. W 1950 roku w Instytucie Urbanistyki i Architektury w Warszawie, gdzie pracował do 1955 roku, otrzymał tytuł samodzielnego pracownika naukowego (Lenkiewicz, 1991). Od 1952 roku na Wydziale Ogrodniczym SGGW prowadził wykłady z zakresu kompozycji roślinnych i historii sztuki ogrodowej. W 1958 roku otrzymał nominacje na stanowisko docenta w Katedrze Urządzania Terenów Zieleni na Wydziale Ogrodniczym SGGW, gdzie pozostawał do swojej śmierci we wrześniu 1958 roku (Zielonko, 1958). Jeszcze w 1953 roku Polska Akademia Nauk powołała Zygmunta Hellwiga na stanowisko sekretarza organizacyjnego komitetu ds. budowy ogrodu botanicznego w Powsinie, co zaowocowało jego wstępnymi pracami nad budowa obiektu w 1956 roku (Lenkiewicz, 1991).

Zygmunt Hellwig był blisko związany z Warszawa - był autorem wielu zrealizowanych tu projektów, m.in.: Parku im. gen. Józefa Sowińskiego (1936, nagrodzony), Zieleńca Wielkopolskiego (1938), Parku im. gen. Gustawa Orlicz-Dreszera (1938), zieleńca na pl. Inwalidów (1938), Parku 13 Września 1944 roku (obecnie - im. płk. Jana Szypowskiego „Leśnika”, projekt z 1944 r., realizacja w 1952 r.), Parku im. Hanki Sawickiej (obecnie im. Obwodu Praga AK, 1953; rys. $9,11,12)$. Inne najważniejsze dokonania to: Park im. Jana Matejki w Łodzi (1924), Park Zdrowia w Ciechocinku (1932), Ogród Botaniczny w Łodzi (III miejsce w konkursie), ogród przy kościele w Podkowie Leśnej (1934), alpinarium Ogrodu Botanicznego w Poznaniu (1938) (Kurzyńska, 2008), cmentarz wojenny żołnierzy Wojska Polskiego poległych we wrześniu 1939 roku w Ożarowie Mazowieckim (1940) (Bohaterowie1939.pl, b.d.). Był szeroko cenionym, wybitnym znawcą roślin i kompozycji roślinnych (rys. 10). Był autorem publikacji książkowych: Ogród w Bożeninie - Listy o kwiatach, 1936; Dobory drzew, krzewów i bylin. Materiaty dla potrzeb planowania i realizacji zieleni w krajobrazie otwartym i zabudowanym, 1951; Założenia programowe parków ludowych (par-

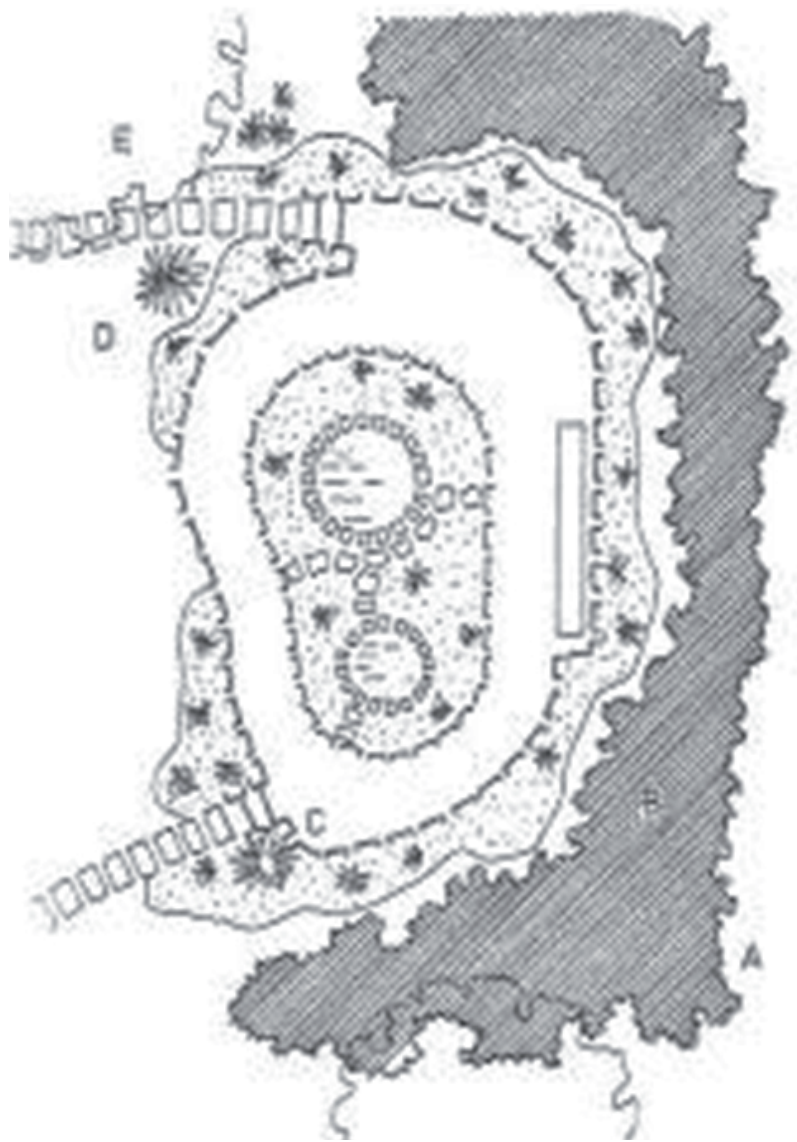

Rys. 10. Z. Hellwig był mistrzem w kompozycjach roślinnych - projekt wgłębnika z basenikiem i kolekcją roślin wodnych, bagiennych, nadwodnych (Korzeniewski, 1989)

Fig. 10. Z. Hellwig was a master in plant compositions - boulingrin project with a basin and a collection of water, marshy and aquatic plants (Korzeniewski, 1989)

ków kultury), 1953; Kwietniki, 1957; Byliny w parku i ogrodzie, 1957; wspóltworzył Urzq̨dzanie terenów zielonych, 1953 (z B. Lisiakiem, W. Sieroszewskim, K. Wiznerem i A. Zielonko); Drzewoznawstwo, 1955 (z S. Białobokiem). Napisał ponad 100 artykułów i sprawozdań ze zjazdów i z kongresów, na które opracowywał w zespole referaty (międzynarodowe kongresy architektów w Essen, Wiedniu, Zurichu, Waszyngtonie) (Zielonko, 1958; Tkaczyk-Piechna, 1999). Za swą twórczość i długoletnią pracę zawodową Zygmunt Hellwig został uhonorowany Złotym Krzyżem Zasługi (Lenkiewicz, 1991). 


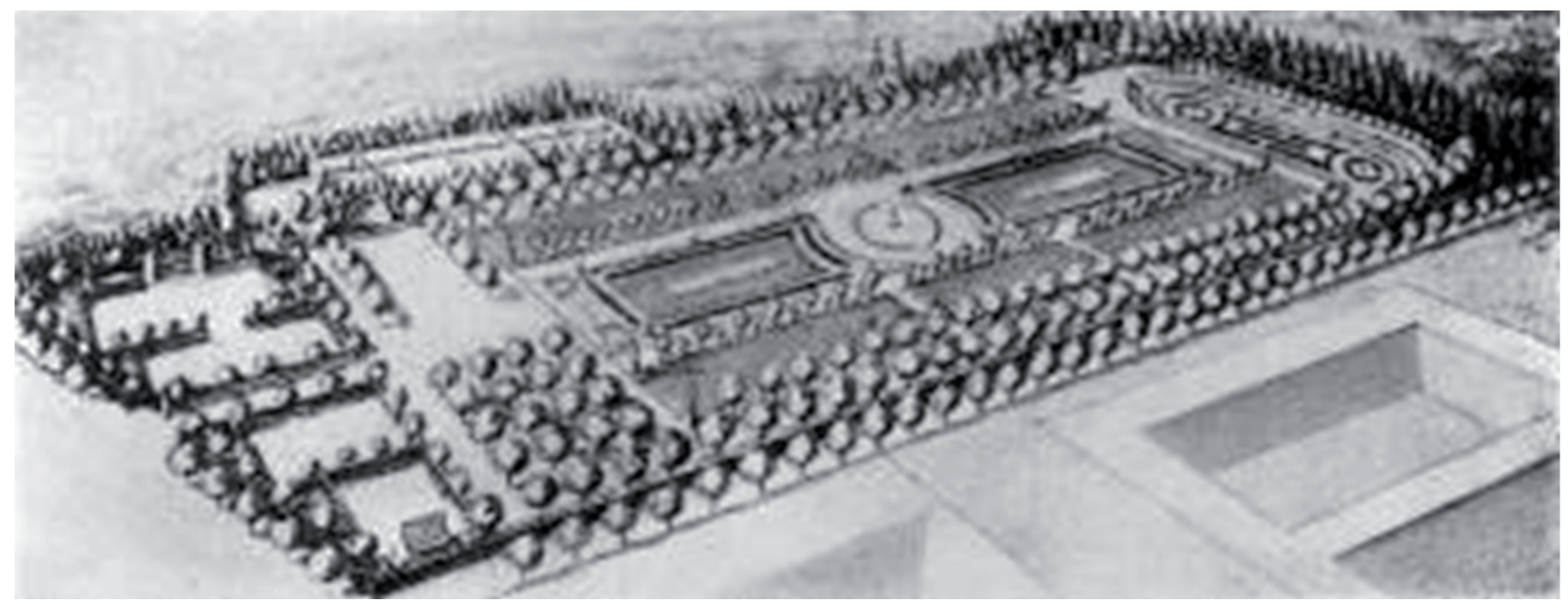

Rys. 11. Park Sowińskiego w Warszawie, 1936 (Majdecki, 1981)

Fig. 11. Sowiński Park in Warsaw, 1936 (Majdecki, 1981)

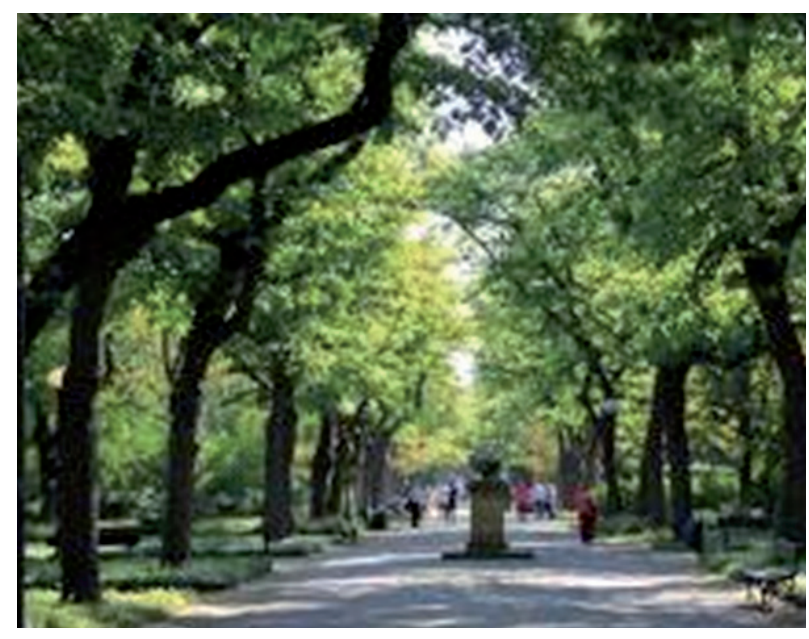

Rys. 12. Park im. gen. G. Orlicz-Dreszera w Warszawie (fot. B. Fortuna-Antoszkiewicz, sierpień 2017)

Fig. 12. The General G. Orlicz-Dreszer Park in Warsaw (photo by B. Fortuna-Antoszkiewicz, August 2017)

\section{Alina Zofia Scholtz-Richert (1908-1996)}

Alina Scholtzówna należy do pierwszego pokolenia absolwentów warszawsko-ursynowskiej szkoły architektury krajobrazu w SGGW (studia w latach 1926-1932 na Wydziale Ogrodniczym). Promotorem jej pracy dyplomowej (Projekt parku strojnego przy Zamku Królewskim w Warszawie) ukończonej w 1932 roku w Zakładzie Architektury Krajobrazu i Par- koznawstwa był prof. F. Krzywda-Polkowski (Kolendo-Kępkowicz, 1998). Jeszcze podczas studiów (lata 1931-1932) wyjechała do Wielkiej Brytanii na stypendium Funduszu Kultury Narodowej. Po studiach pracowała na stanowisku asystenta w Zakładzie Architektury Krajobrazu SGGW (1934-1939) oraz asystenta w Katedrze Urbanistyki na Wydziale Architektury Politechniki Warszawskiej (1937-1939) (Kicińska, 2000). Wielkim sukcesem młodej, uznanej już projektantki była paryska międzynarodowa wystawa Sztuka i Technika w Życiu Współczesnym w 1937 roku - ogród przy pawilonie polskim zrealizowano według jej koncepcji (Chmielewska, 2009; Leśniakowska, 2009; rys. 13-14), a także wraz z Romualdem Guttem otrzymała srebrny medal za pochodzący z 1934 roku projekt (z realizacją) domu jednorodzinnego przy ul. Kieleckiej w Warszawie (Sztuka Architektury.pl, 2000). W latach 30. Alina Scholtz wykonała wiele projektów, w większości zrealizowanych, m.in.: projekt ogrodu przy pałacu Brühla w Warszawie, spektakularny projekt terenów zieleni przy torze wyścigów konnych na Służewcu (Radwan, 1939; Ziemiańska, 2009), parku na Błękitnych Źródłach koło Tomaszowa Mazowieckiego (Kolendo-Kępkowicz, 1998). W tym okresie współpracowała z R. Guttem (np. projekt otoczenia dworku Piłsudskich w Zułowie, 1935; rozplanowanie otoczenia kopca Marszałka Piłsudskiego na Sowińcu, 1936) oraz z prof. Krzywda-Polkow- 
skim (projekt Parku im. H. Derdowskiego w Hallerowie-Wielkiej Wsi, 1939; projekt otoczenia dworku w Żelazowej Woli wraz z nadzorem realizacyjnym). W czasie drugiej wojny światowej Alina Scholtz przebywała w Żelazowej Woli, sprawując dalszą opiekę nad obiektem (Kolendo-Kępkowicz, 1998; Kicińska, 2000). Po zakończeniu wojny powróciła do Warszawy, gdzie w latach 1948-1949 pracowała w SGGW jako adiunkt kontraktowy w Zakładzie Architektury Krajobrazu i Parkoznawstwa kierowanym przez prof. Krzywda-Polkowskiego (Kolendo-Kępkowicz, 1998). W 1949 roku rozpoczęła prace w Pracowni Zieleni w Biurze Odbudowy Stolicy (BOS), późniejszym Biurze Urbanistycznym Warszawy (BUW) (do 1959 r.). W tym okresie zaprojektowała, m.in.: zieleń w otoczeniu Trasy W-Z (np. skarpa przy kościele Św. Anny - wspólnie z M. Wyganowską); Park Ludowy w Warszawie (zrealizowano jedynie fragment, nazwany później Parkiem na Powiślu, 1959; rys. 16); Cmentarz Poległych w Powstaniu i Pomnik Męczenników Majdanka w Lublinie (wspólnie z R. Guttem) (Kolendo-Kepkowicz, 1998; Kicińska, 2000). Przez wiele lat ściśle współpracowała z architektem R. Guttem - ich wspólne projekty cechuje styl, który określić można jako unikalną odmiane polskiego art deco (Rylke, 2016). Jako przykład może służyć projekt rewaloryzacji Ogrodu Saskiego w Warszawie po drugiej wojnie światowej (1948-1949). Innymi ważnymi

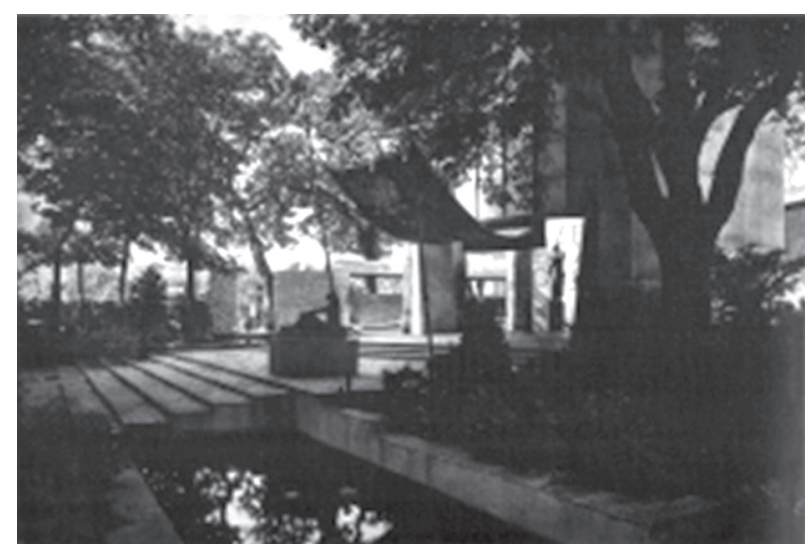

Rys. 13. Fragment ogrodu przy pawilonie polskim, Wystawa paryska 1937 roku (Chmielewska, 2009)

Fig. 13. A fragment of the garden at the Polish pavilion, Paris Exhibition 1937 (Chmielewska, 2009) opracowaniami są m.in.: projekt stadionu praskiego w Warszawie -opracowanie konkursowe ze współudziałem R. Gutta, W. Gepperta, M. Gutt (Wirszyłło, 1955); nagrodzony projekt ogrodu przy Ambasadzie Chińskiej w Warszawie z 1960 roku (z R. Gutta i T. Zielińskiego); projekty ogrodów przy Ambasadzie PRL w Pekinie (z Z. Karpińskim i J. Kowarskim) oraz przy Ambasadzie PRL w Phenian (z R. Guttem, W. Nowakiem i T. Zielińskim); projekt zagospodarowania terenu byłego więzienia na Pawiaku (z R. Guttem); projekt cmentarza w Palmirach (z R. Guttem); projekt zagospodarowania stoków Cytadeli i Parku pod Cytadelą (z M. Wyganowską); projekty zieleni na głównych placach Warszawy - Inwalidów, Wilsona, Unii Lubelskiej; ogrody tarasowe przy Pałacu pod Blachą; projekt zieleni Wybrzeża Kościuszkowskiego; projekt Centralnego Ogrodu Botanicznego w Powsinie (z R. Guttem i W. Nowakiem); projekt ogrodu przy Hotelu Urzędu Rady Ministrów (z T. Zielińskim); projekt zieleni przy Domu Kultury w Zawierciu (z T. Zielińskim) (Kolendo-Kępkowicz, 1998; Kicińska, 2000). W latach 1959-1980 w zespole kierowanym przez prof. Haline Skibniewską (pracownie WSM, Kombinat Budownictwa Miejskiego, Inwestprojekt) Alina Scholtz współpracowała przy projektach warszawskich osiedli mieszkaniowych, m.in.: Sady Żoliborskie WSM, Sadyba-Bonifacego, Sadyba-Fosy, Białołęa Dworska, Batory-Wschód, Szwoleżerów. Była laureatką licznych konkursów projektowych, zdobywając siedem głównych nagród oraz inne wyróżnienia (Kolendo-Kępkowicz, 1998; Kicińska, 2000). Jej publikacje

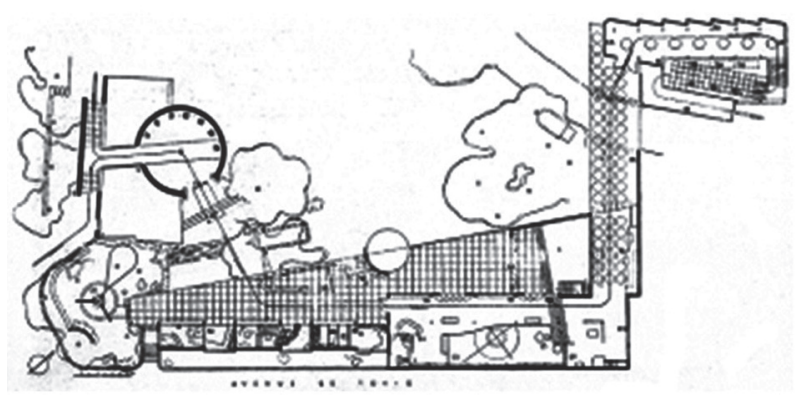

Rys. 14. Plan pawilonu polskiego z ogrodem, Wystawa paryska 1937 roku (Sosnowska, 2009)

Fig. 14. Plan of the Polish pavilion with a garden, Paris Exhibition 1937 (Sosnowska, 2009) 


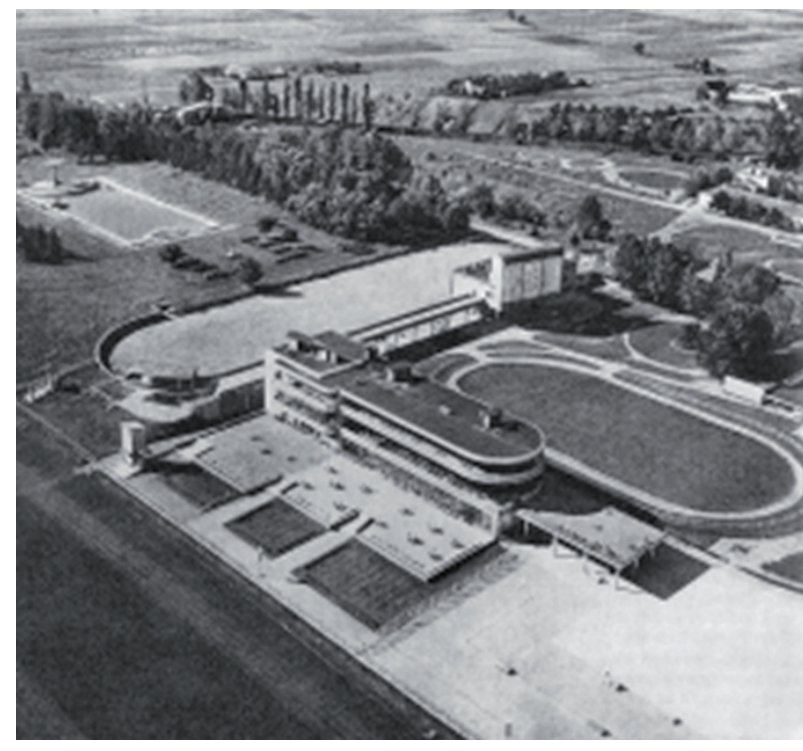

Rys. 15. Tor wyścigów konnych na Służewcu, zbudowany w latach 1938-1939, fot. E. Kupiecki (Rogowski, 1981)

Fig. 15. Horse-racing track in Służewiec, built in 1938-1939, photo by E. Kupiecki (Rogowski, 1981)

to: Projekt Parku Strojnego przy Zamku Królewskim w Warszawie, 1934; Ogródki nowe, 1937 (wydane przez Stowarzyszenie Pracowników Księgarskich, Warszawa); współautorstwo: Rekreacja w osiedlu, 1976 (z K. Piątkowską i R. Wierszyłło, wydane przez Zakład Wydawnictw CRS, Warszawa) (Kolendo-Kępkowicz, 1998; Tkaczyk-Piechna, 1999).

Od 1938 roku była członkiem Towarzystwa Urbanistów Polskich, a od 1946 roku Stowarzyszenia Architektów Polskich (do 1964 r. koordynator Sekcji Architektury Krajobrazu). W 1948 roku brała udział w światowej konferencji architektów krajobrazu w Londynie, na której była jednym z członków-założycieli międzynarodowej organizacji skupiającej architektów krajobrazu - International Federation of Landscape Architecture - IFLA. Delegatem SARP do IFLA pozostała do 1977 roku. W czasie swej długoletniej i obfitej w wybitne dokonania działalności projektowej Alina Scholtz uzyskała liczne nagrody i odznaczenia, w tym status twórcy przyznany przez Ministra Kultury i Sztuki (Kicińska, 2000).

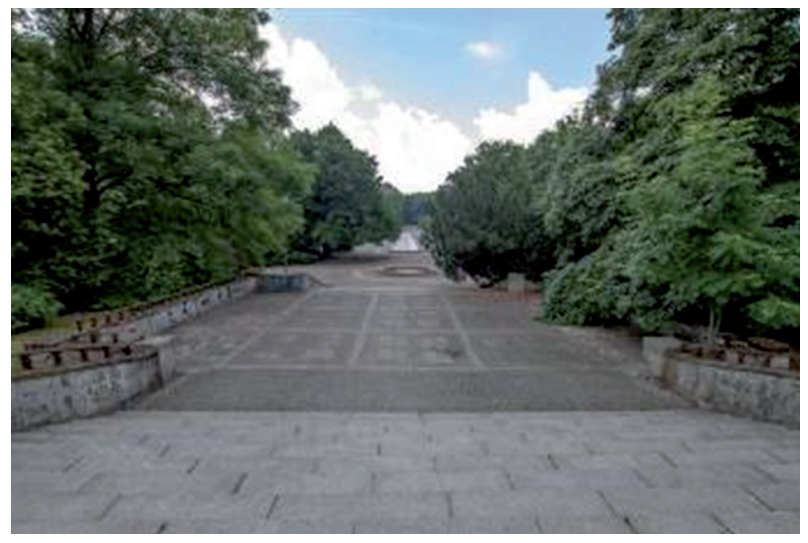

Rys. 16. Park Ludowy w Warszawie - park na Powiślu, obecnie park im. Marszałka E. Rydza-Śmigłego (fot. B. Fortuna-Antoszkiewicz, czerwiec 2018)

Fig. 16. People's Park in Warsaw - a park in Powiśle, currently Marshal E. Rydz-Śmigły park (photo by B. Fortuna-Antoszkiewicz, June 2018)

\section{PODSUMOWANIE}

Dokonania zaprezentowanych postaci - wielkich twórców - na trwale wpisały się w historię architektury krajobrazu w Polsce. Ich obecność na arenie międzynarodowej przyczyniła się do rozwoju tej dziedziny w kraju, co skutkowało światowym poziomem polskich projektów i realizacji - zarówno w sprzyjającym okresie międzywojennym, jak i w odmiennych realiach czasów powojennych. Szczególnie cenna była ich praca na niwie dydaktycznej i edukacyjnej - swą wiedzę i rozległe doświadczenie skutecznie przekazali kilku generacjom nowych adeptów zawodu. Dzięki temu na przestrzeni lat ursynowska szkoła architektury krajobrazu stała się liczącą „kuźnią” młodych architektów krajobrazu i ważnym ośrodkiem rozwijania teorii na styku z praktyką.

Architektura krajobrazu w dzisiejszej Polsce roz-wija się nadal, czego dowodem są kolejne prężne placówki akademickie, które od końca lat 90. XX wieku licznie wykrystalizowały się w całym kraju. Efektem tego są wielokierunkowe, stymulujące badania przyrodnicze i krajobrazowe, a także intensywne działania w sferze publicznej - modernizacje obiektów oraz przekształcenia wizerunkowe miast 
i obszarów wiejskich. Autorzy publikacji, absolwenci „Ursynowa”, żywią głębokie przekonanie, że w znacznej mierze przyczyniła się do tego właśnie ich Alma Mater i działający tu przez lata wielcy mistrzowie - twórcy i kontynuatorzy ursynowskiej szkoły architektury krajobrazu w Warszawie.

\section{PIŚMIENNICTWO}

Bohaterowie1939.pl (b.d). Bohaterowie Bitwy nad Bzurq. Pobrano z lokalizacji: http://www.bohaterowie1939. pl/_content.php? $\mathrm{a}=$ cementary\&itemID=114 (dostęp 07.10.2018).

Chmielewska, A. (2009). Odrębność kulturowa narodu, jego duch i siła, czyli reprezentacja Polski na wystawie paryskiej. W J. M. Sosnowska (red.), Wystawa paryska 1937 (strony 89-104). Warszawa: Instytut Sztuki PAN.

Dolatowski, J. (2016). Zygmunt Hellwig i jego szkółki bylin. Rocznik Polskiego Towarzystwa Dendrologicznego, 64, 47-57.

Howard, E. (1902). Garden Cities of To-morrow. London: Swan Sonnenschein \& Co.

Kicińska, E. (2000). Zieleń Warszawy $w$ opracowaniach Pracowni Zieleni BOS, BUW, PUW, BPRW 1945-1991 r. Warszawa: Gmina Warszawa-Centrum.

Kiciński, M. (1995). Architekci krajobrazu - absolwenci SGGW w latach 1931-1990. Diariusz Katedry Projektowania w Architekturze Krajobrazu, 2, 65-118.

Kolendo-Kępkowicz, A. (1998). Alina Scholtz. Diariusz Katedry Projektowania $w$ Architekturze Krajobrazu, 5, 42-58.

Korzeniewski, W. (1989). Budownictwo mieszkaniowe. Poradnik projektanta. Warszawa: Arkady.

Kurzyńska, A. (2008). Działalność projektowa Zygmunta Hellwiga w Warszawie (praca magisterska). Warszawa: SGGW.

Le Corbusier, (2012). W stronę architektury [Vers une architecture]. Warszawa: Centrum Architektury.

Lenkiewicz, W. (1991). Zygmunt Hellwig - projektant parków. Komunikaty Dendrologiczne, 19, 34-35.

Lenkiewicz, W. (1993). Wspomnienia: Prof. Franciszek Krzywda-Polkowski (1881-1949). Komunikaty Dendrologiczne, 22, 54-56.

Leśniakowska, M. (2009). ”Wielka Szyba” Brukalskiej. W J. M. Sosnowska (red.), Wystawa paryska 1937 (strony 153-167). Warszawa: Instytut Sztuki PAN.

Lynch, K. (1960). The Image of the City. Cambridge: MIT Press.

Majdecka-Strzeżek, A. Niemirski, M. Szumański M. (b.d.). Prof. Franciszek Krzywda-Polkowski (1881-1949). Po- brano z lokalizacji: http://kak.sggw.pl/pl/historia/2-uncategorised/177-franciszek-krzywda-polkowski (dostęp 06.09.2018).

Majdecki, L. (1981). Historia ogrodów. Warszawa: PWN.

Niemirski, A. (1995a). Franciszek Krzywda Polkowski (1881-1949). Diariusz Katedry Projektowania w Architekturze Krajobrazu, 2, 9-11.

Niemirski, A. (1995b). Profesor Alfons Zielonko. Diariusz Katedry Projektowania w Architekturze Krajobrazu, 2, 12-18.

Piechna, B. (1995). Rys historyczny oddziału architektury krajobrazu. Diariusz Katedry Projektowania w Architekturze Krajobrazu, 2, 6-8.

Radwan, M. (1939). Tor na Służewcu. Jeździec i Hodowca, 17,361 .

Rogowski, R. (1981). Konny sport w Warszawie. W Z. Bartoszewska, M.M. Drozdowski, S. Jankowski, J. Odrowąż Pieniążek, A. Rottermund i H. Szwankowska (red.), Jesteśmy $w$ Warszawie. Miasto dawne i nowe (strony 286-297). Warszawa: Państwowy Instytut Wydawniczy.

Sosnowska, J. M. (red.) (2009). Plan pawilonu polskiego (2009). W Wystawa paryska 1937 (strona 322). Warszawa: Instytut Sztuki PAN.

Sztuka Architektury.pl (2000). Romuald Gutt - portret architekta. Pobrano z lokalizacji: http://sztuka-architektury.pl/article/7955/romuald-gutt (dostęp 18.09.2018).

Rozporządzenie Ministerstwa Wyznań Religijnych i Oświecenia Publicznego z dnia 26 września 1923 r. w sprawie powołania specjalizacji $\mathrm{w}$ zakresie projektowania oraz urządzania parków i ogrodów na Wydziale Ogrodniczym SGGW.

Rybczyński, W. (2000). A Clearing In The Distance: Frederick Law Olmsted and America in the 19th Century. New York: Simon and Schuster.

Rylke, J. (2016). Warszawska szkoła architektury krajobrazu. Sztuka Ogrodu, Sztuka Krajobrazu, 1 (14), 34-35.

Rylke, J. i Dzięcioł, J. (red.) (1998). Jubileusz 90-lecia urodzin Profesora Alfonsa Zielonko. Warszawa: Wydawnictwo SGGW.

Schultz, C. N. (1971). Existence, Space \& Architecture. London: Studio Vista.

Tkaczyk-Piechna, B. (1997). W poszukiwaniu architektoniki; dwa parki - pomniki autorstwa prof. Franciszka Krzywdy-Polkowskiego. W J. Rylke (red.), Przyroda i miasto. T. I. (strony 143-159). Warszawa: Wydawnictwo SGGW.

Tkaczyk-Piechna, B. (1999). Teoria architektury krajobrazu w okresie międzywojennym zawarta w publikacjach z tego okresu. W J. Rylke (red.), Przyroda i miasto. T. II (strony 61-87). Warszawa: Wydawnictwo SGGW. 
Tkaczyk-Piechna, B. (2000). Hellwigowska wizja ogrodu $\mathrm{w}$ jego publikacjach z okresu międzywojennego. W J. Rylke (red.), Przyroda i miasto. T. III (strony 103119). Warszawa: Wydawnictwo SGGW.

Tołwiński, T. (1937). Urbanistyka. T. II. Budowa miasta współczesnego. Warszawa: Wydawnictwo Zakładu Urbanistyki (dawn. Zakład Budowy Miast) Politechniki Warszawskiej.

Tołwiński, T. (1939). Urbanistyka. T. I. Budowa miasta w przeszłości. Wyd. 2. Warszawa: Wydawnictwo Zakładu Urbanistyki Politechniki Warszawskiej.
Tołwiński, T. (1963). Urbanistyka. T. III. Zieleń w urbanistyce. Warszawa: PWN.

Wirszyłło, R. (1955). O kompozycji terenów i urządzeń kultury fizycznej. Prace Instytutu Urbanistyki i Architektury, 5, 2 (15), 63-98.

Zielonko, A. (1958). Docent Zygmunt Hellwig. Przeglad Ogrodniczy, 11, 26-27.

Ziemiańska, J. (2009). Modernizacja terenu Torów Wyścigów Konnych na Stużewcu w Warszawie (praca magisterska). Warszawa: SGGW.

\section{URSYNÓW SCHOOL OF LANDSCAPE ARCHITECTURE - MASTERS AND THEIR WORK (PART 1)}

\section{ABSTRACT}

The quality of life, especially in cities, depends on properly shaped and organized space, adapted to specific functions and needs of its users - regardless of times and design trends. Formerly named parks' expertise, today's landscape architecture both grew on the basis of centuries-old tradition of gardens and parks planning. In Poland, the precursor of higher education and training in this profession was the Warsaw University of Life Sciences - SGGW with its head office in Warsaw, and finally in Ursynów - in the former eighteenthcentury estate of Julian Ursyn Niemcewicz, called Rozkosz. That is how the so-called Ursynów School of Landscape Architecture appeared. The academic profile was shaped by several generations of eminent landscape architects who contributed to the development of landscape architecture both at WULS-SGGW and in general in Poland. These undisputed personalities left behind a number of excellent realizations representing the highest standards of design. These facilities still function, effectively enriching the landscape and urban natural systems. Numerous theoretical studies of their authorship are the foundation for further investigation within the discipline of landscape architecture. This article as a first part of a paper about Polish landscape architects presents: Franciszek Krzywda-Polkowski - a founder of the landscape architecture study programme at WULS-SGGW and a designer of park in Żelazowa Wola; Alfons Zielonko - an effective advocate of locating the head office of WULS-SGGW in Ursynów; Zygmunt Hellwig - a designer of Warsaw parks and an outstanding plants expert; Alina Scholtz - the world-famous co-founder of the International Federation of Landscape Architects (IFLA). This publication is aimed at presenting the individualities of the Polish landscape architecture seniors, so that through the prism of their activities, the specificity and character of the so-called Ursynów School of Landscape Architecture can be shown. The studies and analyses are based on a broad review of literature, design projects and field studies in selected parks.

Key words: landscape architecture, Ursynów, Franciszek Krzywda-Polkowski, Alfons Zielonko, Zygmunt Hellwig, Alina Scholtz 